\title{
FOREIGN AND DOMESTIC CREDITORS IN BANKRUPTCY PROCEEDINGS. REMNANTS OF DISCRIMINATION?
}

\author{
Kurt H. NadelmanN $†$
}

\section{INTRODUCTION}

One of the resolutions adopted by the First Conference of the Inter-American Bar Association ${ }^{1}$ dealt with the protection of foreign investments. The academies, institutes, and associations of lawyers, particularly those which are members of the Inter-American Bar Association, were urged to exert influence in their respective countries in behalf of uniformity in matters relating to foreign investments. It was asked that, in such uniform legislation, principles be included which, while assuring the integrity and economic and commercial progress of each country, shall at the same time afford the foreign investor sufficient protection to encourage such investments. ${ }^{2}$

Any law relating to the exercise of creditor rights and which differentiates between domestic and foreign creditors by granting priority rights to the former, is, in fact, in opposition to this resolution. If foreign creditors are to be paid only after payment of domestic creditors, they are not sufficiently protected.

It is a wide-spread belief that, in some countries, such discrimination between foreign and domestic creditors still exists. If this is true, a change will not be effected merely by passing resolutions of a general character. Cases of alleged discrimination must be cited to insure clarification, and to provoke modification in the domestic legislation, if necessary.

Foreign criticism of domestic legislation is often resented, especially if the questions involve fairness to other countries. ${ }^{3}$ In a world

†J.U.D., University of Freiburg in Breisgau; Lic. en Dr., University of Paris; Research Fellow in Comparative Law, University of Pennsylvania. Co-editor, Annales de Droit Commercial: Supplément Documentaire sur le Droit Comparé des Faillites et des Concordats. Author of The Recognition of American Arrangements Abroad (1942) 90 U. OF PA. L. Rev. 780, Spanish translation in (1943) 29 Revista Jurf́dica ARgentina LA LEY, and of numerous other articles in legal periodicals.

I. Havana Conference, r94r, Resolution No. II.

2. (I94I) 39 Revista de Derec ing Events at the Havana Conference of the Inter-American Bar Ass'n (I94I) $8 \mathrm{~J}$. D. C. BAR Ass'N 199, 442, 444, (1942) 20 CAN. B. Rev. 28, 47. Cf. Eduardo Salazar, Futuros inversionistas extranjeros y sus relaciones con la legislación interna de cada país (I941) 27 Revista Forense (Quito) No. 133, reprinted in Salazar, Problemas AMERICANOS (Quito 1942).

3. "For the salvation of mankind it is imperative that whoever may be called upon today to judge the laws, customs, institutions, the habits, acts or thoughts of another nation, should thoughtfully bear in mind the admirably sage advice which the great Spaniard put in Quixote's mouth, advice addressed to Sancho Panzo as he was leaving 
at peace it may be assumed that no country would be deliberately unfair to creditors of other countries. Moral reasons and a fear of retaliation dictate this policy. If, nevertheless, criticism is voiced abroad, it should be given consideration without resentment. Comparison of the domestic with foreign law may reveal that, as a result of differences, a seemingly fair provision has unsuspected discriminatory effiects internationally.

Recent investigations conducted by the International Chamber of Commerce ${ }^{4}$ do not reveal any provisions in bankruptcy statutes now in force, that discriminate among creditors because of their nationality. Such discrimination belongs to the past. ${ }^{5}$ A well-known episode in the struggle for equality among all creditors is the incident between France and a Swiss Canton in I784. In Schaffhausen, domestic creditors had been preferred to French creditors in a bankruptcy proceeding. Louis XVI decreed that citizens of the Canton of Schaffhausen would be paid in bankruptcy proceedings in France only after payment in full of all French creditors; that they would be admitted on equal terms, however, if a reciprocal equality would be guaranteed in Switzerland. Soon afterwards, assurances to that effect were given. ${ }^{6}$ Vestiges of the lengthy struggle for equality ${ }^{7}$ are statutory provisions in some countries which declare foreign creditors are to be admitted only on the basis of reci-

to take up the government of his island: 'No te ciegue la pasión propria en la causa ajena; que los yerros que en ella hicieres las más veces serán sín remedio; y si le tuvieron, será a costa de du crédito, y aun de tu hacienda' (Let not private affection blind thee in another man's cause; for the errors committed thereby are often without remedy, and should it be chargeable with one, it would be at the expense both of their reputation and fortune)". LEvy-UllmaNN, The ENGLISH Legal Tradition. ITS Sources AND History (Mitchell and Goadby trans. 1935) Ivi.

4. See report Levêque, Annales de Droit Commerciat, i939, Supplément DocuMIENTAIRE SUR IE DRoIT CoMrparé DES FAILlites, No. 3, Io (the investigation of the International Chamber of Commerce covered the following countries: Austria, Belgium, Czechoslovakia, Estonia, Finland, France, Great Britain, Luxemburg, the Netherlands, Norway, Poland, Sweden, Switzerland, U. S. A.).

5. "This question of priority granted to citizen creditors, that is a question of 'Peaux-Rouges' jurisdiction; it happens among savages, but not in a civilized State. Today, in all countries of the world, all creditors, without consideration of nationality and domicile, are admitted in bankruptcy proceedings." Jitta, presiding at The Hague Congress (I92I), International Law Assoctatton, 3oth Report, I, 404. Cf. Meiti, DIE GESCHICHTLICHE ENTWICKLUNG DES KonkURSREChtS (Zurich Igo8); idem, Revue de Droit International Privé (IgII) 816, 821.

6. See Lévy-Bruhl, Recherches sur la réglementation internationale des faillites au I8e siccle: France-Ville de Francfort; France-Cantons Suisses, REVUE CRITIQUe DE DROIT INTERNATIONAL, 1938, I75; MEILI, EIN HISTORISCHES INTERMEZZO ZWISCHEN FrankReich UNd deR SchWeIz betr. die internationale Stellung der KonkURSGLÄUBIGER (Zürich I909).

7. Cf., e. $g$., the resolution adopted by the International Congress of Commerce and Industry held in Paris in I889, JouRnaL DU DROIT INTERNATIONAL (hereafter cited ClunET), I892, II I9; Contuzzi, De la nécessité d'assurer aux étrangers le même traitement qu'aux nationaux dans la répartition des produits de la faillite, CIUNET, I892, 1105 . 
procity, ${ }^{8}$ or reserve to the government the right to exclude creditors of a particular country as a measure of retaliation. ${ }^{9}$

If distinctions are still made they are based upon domicile, and not upon nationality. Practically, this type of differentiation amounts to the same thing, but the fight against it has proved more difficult because of inadequate representation of the interests of "non-resident creditors". ${ }^{10}$ Generally, discrimination between resident and non-resident creditors has also disappeared. No existing bankruptcy statute categorically grants priority to local creditors over creditors residing abroad. It is said, however, that remnants of such discrimination are still in existence. A Répertoire of International Law ${ }^{11}$ of world-wide circulation published in France in 1930, lists, as the remaining countries in which priority rights are granted to local creditors, the United States and several countries in South America. Nothing is more detrimental to the development of international commerce and to mutual understanding between nations than any uncertainty about the treatment of foreign creditors. It would seem, therefore, to be of general interest to examine in all frankness the accuracy of the assertion in the Répertoire.

8. Austria. Bankruptcy Code, § 58, Arrangement Law, § 28 (2): "When nothing else results from treaties or from governmental declarations published in the Law Gazette, foreign creditors have the same rights as inland creditors if reciprocity is guaranteed. In case of doubt as to the observance of reciprocity the Minister of Justice is to be asked for a binding declaration. These prescriptions apply also to claims transferred after bankruptcy declaration from foreign to inland creditors."

In a declaration of the Austrian Government made in I924, the following countries were listed as those in which equal admission of Austrian creditors was guaranteed: England, France, Greece, Hungary, Norway, Poland, Sweden, Switzerland, Syria, U. S. A. (J. M. V. BL. I924, 58).

Same provision as in the Austrian law: in the law of CzechoslovaKIa ( $\$ 60$ and 32 , respectively), and of YugosLavia ( $\$ \$ 57$ and 28 , respectively).

Similar provision in Hungary's Bankruptcy Code, \$7I.

9. Germany. Bankruptcy Code, $\S 5:$ "(I) Foreign creditors and inland creditors are on the same footing. (2) The Government may decree that there shall be a right of reprisal against a foreign state and its subjects and their successors."

Reprisals as foreseen have never been decreed by the German Government. See I E. JAEGER, KoMMENTAR ZUR KoNKURSORDNUNG (6/7th ed. 1931) §5.

Io. Compare the treaty text proposed at the $4^{\text {th }}$ Conference of Private International Law, The Hague, I904: "No privilege will result from the nationality or the domicile of the creditors" (ACTES DE LA 4E CONFERENCE $5 \mathrm{I}$ ), with the final text, art. 9, adopted by the 5th Conference, The Hague, I925): "In any bankruptcy, creditors citizens of one of the contracting states are entirely assimilated to the citizen creditors" (ACTES DE LA 5E CONFERENCE 353, CLUNET, 1926, 823).

Also in the treaties of Friendship and Commerce the protection given to nationals of the contracting states generally does not render impossible discrimination based on "residence". Cf., e. $g$., the American standard form of treaty of Friendship and Commerce, reprinted in Wigmore, A Guide to American International Law and PracTICE (r943) III, $\$ 35$.

II. 8 Lapradelle et Niboyet, REpertoire de Droit International (1930) 286 et seq.: Faillite by VALENSI. 


\section{United States}

Concerning the law of the United States, the Répertoire states under the heading "Bankruptcy declared abroad": "In fact, the law as established by the decisions of the Supreme Court in Washington creates a real priority in favor of nationals, and also of creditors domiciled in one State, with respect to creditors from abroad, even if their claim is later in date." 12 From the citation which follows it appears that the writer had in mind a decision rendered by the Supreme Court of the United States in 1907 in Disconto Gesellschaft $v$. Umbreit. ${ }^{13}$

In Disconto Gesellschaft $v$. Umbreit a debtor declared bankrupt in Germany brought assets into the United States and deposited them in a bank in the State of Wisconsin. A creditor in Germany, the Disconto Gesellschaft, tried, by attachment in Wisconsin, to recover these assets for the trustee in the German bankruptcy. Umbreit, a resident of Wisconsin and a subsequent creditor, attacked the validity of the earlier attachment on the ground that the law of Wisconsin does not sustain, against local creditors, rights of a foreign trustee in bankruptcy to local property. He claimed that this principle should be applied also to a suit brought by a foreign creditor in the interest of the foreign trustee in bankruptcy. The Supreme Court of the State of Wisconsin upheld Umbreit and dismissed the suit of the Disconto Gesellschaft. ${ }^{14}$ The Disconto Gesellschaft appealed the case to the Supreme Court of the United States, contending that the law of Wisconsin, as stated by the highest court of that State, violated the Fourteenth Amendment to the Federal Constitution by depriving the Disconto Gesellschaft of property without due process of law. The Disconto Gesellschaft also sought to invoke a provision in the Treaty of 1828 between the United States and Prussia. The Supreme Court of the United States held that there was nothing in the Treaty. "undertaking to change the wellrecognized rule between states and nations which permits a country to first protect the rights of its own citizens in local property before permitting it to be taken out of the jurisdiction for administration in favor of those residing beyond their borders." 15 It was also held that this rule, applied by the Supreme Court of Wisconsin, does not violate the "due process" clause of the Fourteenth Amendment to the Federal Constitution.

I2. Id., No. 714 (author's trans.). A statement to the same effect will be found, e. g., in Caiceno Castilla, Manual de Derecho Internacional Privado (zd ed. Bogota 1939) 290.

13. 208 U. S. 570 (I907) ; 3 Hackworth, Digest of Internattonal Law (I942)

570 (excerpts). Cf. Foreign Relations, I9I0, 518 to 522.

14. I27 Wis. 65I, I06 N. W. 821 (I906).

15. 208 U. S. 570,582 (1907). (Italics supplied.) 
Nothing in this decision, or any other decision of the Supreme Court of the United States, supports the view expressed in the Répertoire that this court has established any rule of priority in favor of nationals, or domestic creditors, as against creditors from abroad. What the court held, and has reaffirmed in recent decisions, ${ }^{18}$ is that no federal question is involved if a state of the Union, following its own law and policy, refuses to recognize external transfers of property situated within its borders, e. g., a transfer resulting from foreign bankruptcy adjudications, which conflicts with the rights of domestic creditors seeking to recover their debts against local property. ${ }^{17}$ This denial of extraterritorial effects to foreign bankruptcy decrees is not only the law in states of the Union, ${ }^{18}$ but also the law in many other parts of the world. ${ }^{19}$

Another, but completely different, question is whether in reference to a distribution of local assets in the United States, state law may provide, or in fact does provide, either by statute or by judicial decision, that claims of creditors residing in the state shall be paid prior to those of creditors resident abroad. In a few states of the Union an attempt has been made to give such a preference to domestic creditors in the administration of the assets of a foreign insolvent. ${ }^{20}$ The decision of the Supreme Court of the United States in Blake v. McClung ${ }^{21}$ shows, for example, that a Tennessee statute ${ }^{22}$ contained such a provision. The Court there held that the Federal Constitution protects citizens of another state of the Union against such discrimination. Creditors, not citizens of the United States, cannot avail themselves of (1935).

I6. Clark v. Williard, 292 U. S. II2 (I934); Clark v. Williard, 294 U. S. 2 II

I7. Cf. Stone, J., in United States v. Belmont, 30I U. S. 324, 335 (1937) : "But it is a recognized rule that a state may rightly refuse to give effect to external transfers of property within its borders so far as they would operate to exclude creditors suing in its courts."

I8. Taylor v. Geary, Kirby 3I3 (Conn. I787) ; Blake v. Williams, 6 Pick. 286 (Mass. 1828); Wallace v. Patterson, 2 H. \& McHen. 463 (Md. 1790); Saunders v. Williams, 5 N. H. 2r3 (1830); Abraham v. Plestoro, 3 Wend. 538 (N. Y. I829), overruling Holmes v. Remsen, 4 Johns. Ch. 460 (N. Y. 1820); McNeil and Colquhoon, 2 Hayw. 24 (N. C. 1797) ; Milne v. Moreton, 6 Binn. 353 (Pa. 1814) ; Topham v. Chapman, I Const. Rep. 283 (S. C. I8I7). Cf. Booth v. Clark, I7 How. 322, 337 (U. S. 1854); Wood v. Parsons, 27 Mich. 159 (1873).

As early as 1809, the U. S. Supreme Court had held that "the bankrupt law of a foreign country is incapable of operating a legal transfer of property in the United States." Harrison v. Sterry, 5 Cranch 289, 302 (U. S. 1809). Cf. Ogden v. Saunders, I2 Wheat. 213,360 (U. S. I827); Security Trust Co. v. Dodd, Mead \& Co., I73 U. S. 624,629 (1899).

19. E. g., Germany, the Netherlands, Sweden, Switzerland, Mexico, Argentina, Paraguay, Peru, Uruguay. See Nadelmann, The Recognition of American Arrangements Abroad (I942) 90 U. of PA. L. REv. 780, 789; idem, El reconocimiento de los arreglos americanos en el exterior (1943) 29 REVISTA JURfDICA ARGENTINA LA LEY (Videla Aranguren and Thamis trans.).

20. Cf. 2 Beale, Conflict of Laws (I935) 988.

2I. I72 U. S. 239 (1898), on further appeal, 176 U. S. 59 (I900).

22. Tennessee Code (Michie, 1938) §4I34. 
the "privileges and immunities" clause of the Fourteenth Amendment to the Constitution. ${ }^{23}$ Payment to foreign creditors could seemingly be deferred until resident creditors were paid, if a state chose to do so. ${ }^{24}$ In most jurisdictions, however, it is either held by the courts or provided by statute that foreign creditors are entitled to share equally with domestic creditors. ${ }^{25}$

From a practical viewpoint, local rules governing distributions in the different states of the Union have lost most, if not all, interest for foreign creditors. Local receiverships have become rare since the federal law has provided for corporate reorganizations. This federal proceeding, ${ }^{26}$ available even if a local receivership is pending, is governed by the rules of the Federal Bankruptcy Act relating to priority rights. The Federal Bankruptcy Act, as modified in 1938, provides that debts have priority if "by the laws of the United States" they are entitled to priority."7 Priorities resulting from state law, and not from federal law, therefore, are not recognized in bankruptcy, reorganization, or arrangement proceedings. ${ }^{28}$

Whether or not, in the United States, claims of domestic creditors are entitled to priority in bankruptcy, corporate reorganization, or arrangement proceedings, is a question now governed by federal law exclusively. No such priority is established by federal law. Neither the Bankruptcy Act nor any other federal statute discriminates between claims of domestic creditors and creditors from abroad. However, such discrimination might possibly be introduced by federal law, ${ }^{29} e . g$., as retaliation.

23. Cf. Restatement, Conflict of Laws (I934) $\S 554$, comment $b$.

24. "On principles of fairness, such policy has nothing to commend it. . . " GoOdrich, HaNDBOOK OF THE CoNflict OF Laws (2d ed. 1938) 52r.

25. See Beale, op. cit. supra note 20. People v. Granite State Provident Ass'n, I6I N. Y. 492, 495 (I900); Matter of People (Norske Lloyd Ins. Co.) 242 N. Y. I48, I64 (I926). However, \$ 977-b, subd. I6, of the New York Civil Practice Act, introduced in 1936, as amended in 1938, now gives priority in the receivership of a foreign corporation to United States residents over non-residents suing on causes of action which did not arise or accrue in the state of New York. The constitutionality of this provision in the New York State law, which also affects American citizens residing outside of the United States, has not yet been tested. In Blake v. McClung, supra note 2I, creditors not residing in the United States were not before the court, and it was not necessary for the Supreme Court of the United States to decide "what may be the effect of the judgment of this court in the present case upon the rights of creditors not residing in the United States" (I72 U. S. 239, 26I (I898)). Cf. Mulder and Solomon, Effect of the Chandler Act upon General Assignments and Compositions (1939) S7 U. of PA. L. Rev. $763,780$.

26. BANkRuptcy Act, c. X, 52 Stat. 883 (I938), il U. S. C. A. \$501 (I939).

27. BANkRUPTCY ACT, $\$ 64$ (a) (5), 52 STAT. 874 (1938), II U. S. C. A. \& 104 (Supp. 1942).

28. Before $\mathrm{I}_{3} 8$, priorities resulting from state law were recognized. The American Bar Association urged the change in the Bankruptcy Act which renders discrimination resulting from state law ineffective. See (1925) A. B. A. REP. 478, 49I.

29. Cf. United States v. Pink, 3I5 U. S. 203, 228 (I94I) (upholding the Litvinov Assignment); see Borchard, Extraterritorial Confiscations (I942) 36 AM. J. INT. L. 275 . 
A few classes of debtors cannot become involuntarily bankrupt under the Federal Bankruptcy Act. ${ }^{30}$ For such debtors insolvency proceedings are governed by state law, in the absence of federal legislation. From the viewpoint of foreign creditors only the insolvency of banking, insurance, and railroad corporations is worthy of mention.

The National Banking Act, a federal statute applicable to all national banks, requires that assets be distributed ratably among all creditors. ${ }^{31}$ A state statute creating discrimination between creditors would be repugnant to the Act. ${ }^{32}$ For banks which are not national banks, state law has.to be consulted. No known state banking statute now in force embodies discriminatory provisions against creditors resident abroad. ${ }^{33}$ Protective measures embodied in state banking laws ${ }^{34}$ protect bank customers irrespective of their nationality or domicile.

State insurance statutes frequently require the deposit of special funds by foreign corporations as a prerequisite to their engaging in local business. If such deposits are construed, as is often the case, as trust funds by foreign corporations as a prerequisite to their engaging in local creditors doing business with the local branch, these creditors become secured to the extent of the special funds. ${ }^{35}$ A reaction against this creation of special guarantees has appeared in recent years. In order to reduce the efficacy of deposit statutes as far as possible, ${ }^{36}$ legislation in some states ${ }^{37}$ provides that in liquidations of general assets, unse-

30. Wage earners, farmers, building and loan associations, a municipal, railroad, insurance, or banking corporation ( $\$ 4$, U. S. Bankruptcy Act).

3I. Rev. Stat. $\S \S 5236,5242$ (1875), I2 U. S. C. A. \$§ 9I, I94 (1936).

32. Cf. Davis v. Elmira Sav. Bank, I6I U. S. 275 (I895); GlenN on LrquidaTION (I935) 404.

33. See 3 Mrchie on Banks and Banking (Permanent edition) § I7; Note (I93I) 44 HARv. L. REv. 6I8, 622; Note (I932) 32 CoL. L. REv. I393; Note (I933) 43 YALE L. J. 346.

34. Cf. Kan. Rev. Stat. (I923) §9-I43, providing that the assets of any private bank shall be exempt from execution by any creditor of the individual or firm doing business as such bank until after the liabilities of the bank have been paid in full. See State v. District Court et al., 75 Mont. 567 (1926); In re Yegen, I F. (2d) 84I (1926) ; State v. Sage, 267 Mo. 492 (1916); Missouri v. Angle. In re Sage, 236 Fed. 644 (Igr6) (decisions dealing with statutory provisions which construe private banks as separate entities apart from all other business of the owner).

35. Bank Commissioners v. Granite State Provident Association, 7o N. H. 557 (1900) ; People v. Granite State Provident Association, I6r N. Y. 492, 498 (I900); Matter of People (Southern Surety Co.), 282 N. Y. 54 (r939), noted (r940) 88 U. of PA. L. REv. ror 8 .

36. If the security is more adequate than the general assets, no means exist to reduce their effectiveness. \$ 833.6.

37. E. g., N. Y. INs. Law §522; Ill. ANn. Stat. (Smith-Hurd, 1934) c. 73, 
cured creditors shall be preferred to secured creditors to the extent necessary to equalize the advantage gained by virtue of such security. ${ }^{88}$

Railroad corporations cannot be declared "bankrupt", but the Federal Bankruptcy Act, in the amended Section $77,{ }^{30}$ provides for a special reorganization proceeding applicable to railroads engaged in interstate commerce. For all purposes of this proceeding, unsecured claims which would have been entitled to priority in a federal receivership are declared entitled to such priority. ${ }^{40}$ On equitable principles, priority for local over non-resident creditors cannot be supported: equality is equity. Federal law does not provide for such a priority, but if the applicable state law so provides, the priority would have to be recognized in the railroad reorganization proceeding. However, the existence of state law priorities for local creditors affecting railroad reorganization proceedings is unlikely.

In summary and contrary to the statement in the Répertoire, the bankruptcy law of the United States does not accord priority rights to nationals or creditors domiciled in the United States, as against creditors from abroad. State laws governing the insolvency of debtor groups to which the Federal Bankruptcy Act does not apply, with rare exceptions, also do not grant such a priority.

\section{South America}

The Répertoire declares that, in South America, various laws, e.g., that of Uruguay, give priority in bankruptcy proceedings to claims of citizens. ${ }^{41}$ The law of Argentine is also mentioned in this connection. The Répertoire reports the provision in the Argentine Bankruptcy Act that, if bankruptcy is declared abroad and in Argentine, creditors of the foreign bankruptcy will be paid in the Argentine bankruptcy only after payment in full of the creditors in Argentine. ${ }^{42}$ The presentation in the Répertoire is misleading as readers may assume that in these countries

38. Uniform Insurers Liquidation Act $\$ 7$, 9 Uniform Laws ANn.: "The owners of special deposit claims against an insurer for which a receiver is appointed in this or any other state shall be given priority against their several special deposits in accordance with the provisions of the statutes governing the creation and maintenance of such deposits. If there is a deficiency in any such deposit so that the claims secured thereby are not fully discharged therefrom, the claimants may share in the general assets, but such sharing shall be deferred until general creditors, and also claimants against other special deposits who have received smaller percentages from their respective special deposits, have been paid percentages of their claims equal to the percentage paid from the special deposit."

39. BANKRUPTCY ACT, \$77, 53 STAT. 1406 (I939), II U. S. C. A. \$205 (r94I). Cf. also Railroad Adjustment Act, Pub. L. No. 747, 77th Cong., 2d Sess. (Oct. 16, I942).

40. Bankruptcy Act, $\$ 77$ (b), 53 Stat. 1406 (I939), i I U. S. C. A. $\$ 205$ (b) (I94I).

41. 8 Lapradelle et Niboyet, op. cit. supra note i I, No. 720.

42. Id., No. 721, referring to Zeballos, De la condition dans la République Argenṫ̉ie des sociétés organisées en pays étranger, CLUNET, I906, 604, I032. 
a priority right is granted to domestic creditors in any bankruptcy proceeding. This is not the case. The general rule for admission in bankruptcy proceedings is that of equality between domestic creditors and creditors from abroad. ${ }^{43}$ It follows ${ }^{44}$ from the fact that only in one fact situation is a distinction made by the law in the treatment of domestic and other creditors. This situation is the case of multiple bankruptcies. If bankruptcy is declared abroad and at home, domestic creditors in the latter bankruptcy are paid with priority. "The bankruptcy also declared by the courts of the Republic shall not take into consideration the creditors belonging to the foreign bankruptcy, except if a surplus remains after payment in full of the creditors in the Republic." This is the text of the provision first appearing in the Commercial Code of the Province of Buenos Aires of 1859 , which became the law of Argentine in 1862, of Uruguay in 1865 , of Paraguay in 1902, and of Peru in 1932, and is still in force in these four countries. ${ }^{45}$

The law of Peru contains another exception to the equality rule. In a bankruptcy proceeding in Peru creditors owning obligations contracted abroad will be admitted equally only to the extent to which the money has, in fact, been invested by the debtor in his business in Peru. The balance may be paid from any existing surplus, after payment of the "proper" debts of the bankruptcy. ${ }^{48}$ This is an additional exception to that of multiple bankruptcies.

What does the priority rule applicable in the case of multiple bankruptcies mean? For example: D, a business man in Buenos Aires with creditors also in the United States is declared bankrupt by the commercial court in Buenos Aires. If bankruptcy is declared only in Argentine, all creditors, foreign and domestic, share equally in the distribution in Buenos Aires. D also has assets in the United States, as a result of occasional transactions there, or because he has an establishment, branch, or agency in that country. On petition of certain creditors, he is also declared bankrupt in the United States by the Federal Court of the District in which the assets are located. C, a creditor in the United States, proves his claim in both bankruptcies. In the United States all creditors will be admitted and paid on the same basis without distinction between domestic creditors and creditors residing abroad. In Argentine, "creditors in Argentine" must be paid in full before

43. I Castilio, La guiebra en el derecho Argentino (i940) No. 105. trario.

44. 9 Malagarriga, Código DE Conercio (3d ed. r929) 64: argumentum a con-

45. Argentine: Bankruptcy Law No. II,7I9 of I933, $₹ 7$ (2); Uruguay: Com. Code, § 1577; Paraguay: Com. Code, § 1383; Peru: Bankruptcy Law No. 7566 of I932, $\S 26(2)$.

46. Bankruptcy Law No. 7566 of I932, § 26 (3). See Sanchez Palacios, Apuntos sobre la Ley 7566 (I939) 3 Revista de DeRecho y Cienctas Polf́ticas 49. 
"creditors belonging to the foreign bankruptcy" can share in the distribution. Following the language of the provision in the Argentine Bankruptcy law, the creditor $C$ would seem to "belong to the foreign bankruptcy" and not to be a "creditor in Argentine"."7 Will he be paid only from a surplus, if any? If such is the case, all creditors from abroad engaged in commerce with persons in any of the countries which have this priority rule must be most seriously concerned. Local assets of an insolvent debtor are generally insufficient to pay even the local creditors. A rule admitting creditors from abroad only after full payment to local creditors means that foreign creditors risk total exclusion from the distribution of, perhaps, the main assets of their debtor.

If equality among creditors is the rule, why discriminate between domestic and foreign creditors in multiple bankruptcies? In the absence of treaties, the possibility of multiple bankruptcies is unavoidable if assets of an insolvent debtor are located in more than one country. Many countries refuse to recognize the effect of a foreign bankruptcy declaration on local assets. ${ }^{48}$ Even if foreign decrees rendered by a competent court were recognized everywhere, multiple bankruptcies would still be possible because the principles of bankruptcy jurisdiction are not uniform. ${ }^{49}$ In some countries, e. g., in Argentine, ${ }^{50}$ the law gives exclusive jurisdiction to the court of the place of the debtor's commercial domicile. In other countries, e. g., in the United States, ${ }^{51}$ a non-resident debtor also can be adjudicated a bankrupt provided that some of his assets are located in the country. Even if the jurisdictional rules were the same and bankruptcy could be declared only by the court

47. No definition of these terms is given in the bankruptcy statute. The Treaty of Montevideo of 1889 , infra page 616, uses the term "local creditors" and defines it. Creditors from a country not party to the Treaty of Montevideo cannot rely upon this definition for the construction of the terms used in the bankruptcy statute.

48. See note ig supra.

49. In general, the court of the commercial domicile of the debtor is given bankruptcy jurisdiction. Often residence is declared sufficient in the absence of a domicile. In some countries, a non-resident can be declared bankrupt if he has a branch $(e . g$., Brazilian Bankruptcy Law, § 7; Dutch Bankruptcy Act, \$ 2 (4); Mexican Commercial Code, $\$ 949$ ), or an estate (German Bankruptcy Code, $\$ 238(2)$ ), or simply assets located in that country (e.g., U. S. Bankruptcy Act, $\$ 2$ (2) (I); Canadian Bankruptcy Act, $\$ 2$ (z) No. 3; Austrian Bankruptcy Act, $\$ 63 .(2))$, or if he has carried on business there (e.g., English Bankruptcy Act, $\$ 4$ (I) (d); Scotch Bankruptcy Act, $\S$ II (in the case of a company); Australian Bankruptcy Act, $\S 55$ (I)), or if the petitioning creditor is a citizen of the country (French law, applying $\S 14$ of the Civil Code). Cf. Ball, Domicile and Bankruptcy Jurisdiction, Internattonal Law AssoCIATION, 30th REPORT (The Hague, I92r) I, 394.

50. Bankruptcy Law No. I1,719 of I933, \$\$ 8 (2), 55 (2).

5I. "The courts of the United States . . are hereby invested ... with ... jurisdiction .... to (I) Adjudge persons bankrupt who have had their principal place of business, resided or had their domicile within their respective territorial jurisdictions for the preceding six months, or for a longer portion of the preceding six months than in any other jurisdiction, or who do not have their principal place of business, reside, or have their domicile within the United States, but have property within their jurisdictions, or who have been adjudged bankrupts by courts of competent jurisdiction without the United States, and have property within their jurisdictions." BANKRUPTCY ACT, § 2 (a) (I) ; 52 STAT. 842 (I938), II U. S. C. A. § II (I94I). 
of the domicile of the debtor, nothing could prevent courts of different countries from disagreeing about the location of the debtor's domicile. ${ }^{52}$

Equal distribution of the debtor's assets among all his creditors, the main purpose of bankruptcy proceedings, is not imperilled by the mere fact that several local distributions must take place because bankruptcy is declared in more than one country. Multiple bankruptcies create many problems, especially in connection with the administration and liquidation of the local assets. ${ }^{53}$ To avoid these difficulties, a great many countries have negotiated, especially with neighbors, treaties in reference to bankruptcy. ${ }^{54}$ Equality among creditors can be secured without treaties. Distribution of a proportionate dividend to all creditors of the same debtor is the automatic, arithmetic result, if in all local distributions all the creditors are admitted without differentiation. Inequality is introduced only if in any one of the distributions a distinction is made and a priority accorded to one group of creditors.

With these facts in mind, it is surprising to find a system which, while accepting equality among all creditors as the general rule, in fact makes this equality dependent upon such a fortuitous element as the existence of only one bankruptcy. Why abandon equality and grant a priority to domestic creditors because some of the assets are located abroad and are the object of a foreign bankruptcy declaration? This question has been asked for more than half a century, and criticism has sometimes been expressed in strong terms concerning this provision in the Argentine and other bankruptcy codes. The opinions expressed on the subject by leading authors in Argentine and Uruguay have been reviewed by an Argentine jurist in a recent paper. ${ }^{55}$ The reviewer cites a contemporary author, Malagarriga, ${ }^{56}$ who declares the rule adopted

52. The conception of "domicile" also differs in the various legal systems. See Kuhn, Comparative Commentaries on Private International Law (1937) 66 et seq. Cf. In re Artola Hermanos, 24 Q. B. D. (1890) 640 (A partnership, formed by persons of Spanish origin, having its principal establishment in France and a branch in England, was declared bankrupt in France. The English court held that prior bankruptcy in France was not shown to be the country of the domicile of the debtors; there was no ground for staying bankruptcy proceedings in England).

53. "It would be in the power of the bankrupt to throw his property under the distribution of either commission, at his pleasure; and it would put creditors upon calculations of exclusive advantages, and of running a race of diligence against each other, and of resorting to the one fund or the other, as circumstances might dictate. The perplexities arising from the concurrent operation of distinct commissions would be increased, if the commercial house had establishments in different countries, with joint and separate debts belonging to each firm, to be distributed. Such a state of things, and such conflicting systems, would lead to great inconvenience and confusion, and be the source of fraud and injustice, and disturb the equality and equity of any bankrupt system." Chancellor Kent in Holmes v. Remsen, 4 Johns. Ch. 460 (N. Y. I820).

54. Bankruptcy treaties exist in Scandinavia, in Western and in Central Europe, and in Latin America. See Nadelmann, sitpra note 19, at 80r.

55. Quesada, Aspecto internacional de la quiebra (194I) 4 Revista DE Derecho Publico y Privado (Montevideo) 67,84 .

56. Malagarriga, supra note 44 , at 64 (author's trans.). 
in the statute "a solution, which, though not to be considered inspired by high principles of international law, must be respected as defence of the interests of internal commerce and as understandable reciprocity towards identical hostility of the foreign legislations." A desire to protect the interests of domestic creditors and a belief in the existence of analogous practices abroad are the arguments advanced by nearly all the authors cited. ${ }^{57}$ If the reciprocity argument is restricted to the assumed cases of identical hostility in foreign legislations, the other argument, defense of internal commerce, ${ }^{58}$ would not explain why the protection of local interests by the priority rule is provided for only in the case of multiple bankruptcies. Segovia, ${ }^{5 \theta}$ referring to a rule in the Roman law, furnishes this additional argument: "The priority given to the creditors belonging to the distribution opened in our country is founded on the fact that the law considers as distinct commercial houses the one which exists in the Republic and the other which may exist abroad; because these creditors have contracted under the guaranty of the assets existing in the country and in taking into account the status of the commercial house."

Segovia's comment, in conjunction with the history ${ }^{60}$ of the text first incorporated in the Buenos Aires Code in 1859 , raise the question whether the priority rule is aimed exclusively at the case of debtors with distinct establishments at home and abroad. Apparently, Segovia assumed that the provision would become effective only in such a case. ${ }^{.1}$ As the Argentine law permits a bankruptcy declaration only at the commercial domicile of the debtor, he may have believed a second bankruptcy declaration impossible except in the case of debtors with distinct establishments abroad. Massé's treatise on Commercial Law ${ }^{62}$ which influenced Vélez Sarsfield, the author of the Commercial Code of 1859 , contains no statement that in any case of multiple bankruptcies priority should be given to local creditors. But the case of a debtor with two establishments, one abroad and one in France, is discussed, and the opinion is expressed that the bankruptcy of the establishment located

57. 5 Rivarola, Tratado de Derecho Comercial Argentino (1940) 39; ArmenGOL, FundaMentos Y CRÍTICA DE LA LEY DE QUIEBras (2d ed. I914) 218; 3 Almancio Alcorta, Derecho Internactonal Privado (2d ed. Ig27) 350.

58. Stressed by Moreno, Estudios sobre quiEbras (1864) 6I ; I Obarrio, Estudio SOBRE LAS QUIEBRAS (I895) 35, who asserts that "local creditors have a priority right on local assets".

59. 3 Segovia, Explicación y critica al nuevo Código de Comercio (i892) note 4555 sub $\$ 1385$ (author's trans.). § I53I.

6o. See Alcorta, Funtes y concordancias der Código de Comercio (i887)

6r. Same, e. g., I (2) Baldassare, Cienctas de administración y legislación (1939) I167.

62. 2 MASSE, LE DROIT COMMERCIAL DANS SES RAPPORTS AVEC LE DROIT DES GENS ET LE DROIT CIVIL (I847) Nos. 809, 810. 
abroad does not affect the establishment in France. ${ }^{63}$ Whether the priority rule in the Codes of Argentine, Paraguay, Peru, and Uruguay, does not apply, or should not be applied, to other cases than that of a debtor with distinct establishments abroad and at home, is a mooted question. ${ }^{64}$ Foreign creditors must be aware of the language of the text ${ }^{63}$ which applies to all cases of multiple bankruptcies. They must also realize that this text has survived ${ }^{66}$ in spite of all criticisms expressed abroad ${ }^{87}$ and at home. ${ }^{88}$

If the provision reads, as Segovia implies, that priority is granted the creditors of the domestic establishment if the debtor has a foreign establishment in bankruptcy, such a rule would have its foundation in this argument: where a debtor has two or more distinct establishments, the creditors of each must be kept separate. To students of Roman law this principle is well known. Ulpian's opinion, included in the Digest of Justinian, ${ }^{69}$ is that the creditors of two distinct business houses of different types, operated by a slave for his master, should be separated because "credit was given more to the business than to the business owner." This rule, a principle of general law and not a conflict of laws rule, remained in force, and thus was preserved throughout

63. Reference is made to App. Brussels, June 6, 1816 , reported in 6 MERLIN, REPERTOIRE DE JURISPRUDENCE (5th ed. I827) c. Faillite, sec. II, \$ 2, art. IO.

64. In Argentine, Prof. Carlos Alberto Alcorta, of the University of La Plata, suggested in 1924 replacement of the text by the provisions contained in the Montevideo Treaty of 1889 (infra, page 616$)$, which are based on the "separate establishment" theory. Alcorta, Régimen internacional de la quiebra (1924) 14 JURISPRUDENCIA ARGENTINA I3O, I34.

Such was the law in Peru until 1932: Ley procesal de quiebras de roo2, \$§ 108 to II4.

65. "This provision is the result of a mistake which I try to dissipate in the text." 2 Thaller, Des failiITes EN DROIT COMPaRE (I887) No. 233, note 2 (author's trans.).

66. In Argentine, a thorough revision of the Bankruptcy Law took place in I933, under the leadership of President Ramón S. Castillo, then Senator and Professor of Commercial Law at the University of Buenos Aires. The text remained unchanged. Castillo's Treatise on Bankruptcy (supra note 43) does not comment upon the priority rule at all.

In Peru, the text had been introduced only in I932; cf. notes 45 and 64 supra.

67. More recently, e. g., Alberic Rolin, DES CONFLITS DE LOIS EN MiATIËRE DE Fatlitie, I4 Recueil des Cours de l'A cademite de Droit International (1926) 45.

68. See, e. g., 2 Carios Calvo, Droit International (5th ed. in French I8g6) No. 9 II in fine; Alcorta, loc. cit. supra note $64 ; 2$ ORIONE, LEY DE QUIEBRAS (I935) 33I.

In his paper read before the Argentine Branch of the International Law Association in I925, Alcorta answered the question as to the fairness of the priority rule in the Argentine Bankruptcy Law by reciting the Franco-Swiss incident of 1784 (supra note 6) with this comment: "It is to be hoped that for a provision resembling that of the Canton of Schaffhausen a case similar to that between Schaffhausen and France may not occur to the Republic of Argentine. This is my desire." Alcorta, supra note 64, at I34 (author's trans.). Reproduced in 4 VICo, CURSO DE Derecho INTERNACIONAL Privado (I927) II5.

69. D. I4-4.5.15: Si plures habuit servus creditores, sed quosdam in mercibus certis, $2 n$ omnes in iisdem confundendi erunt, et omnes in tributum vocandi; utputa duas negotiationes exercebat, puta sagariam et linteariam, et separatos habuit creditores: puto, separatim eos in tributum vocari, unusquisque enim eorum merci magis, quam ipsi, credidit. Cf. 3-4 Scott, The Crvil LAw (1932) 222 for trans. 
the centuries wherever the Roman law, was applied. ${ }^{70}$ The rule was interpreted later as applying to merchants with different establishments at different places, and the idea of separation was also retained for interprovincial cases. ${ }^{71}$ However, the applicability of the rule to an economic system different from that of the Roman Empire was questioned, ${ }^{i 2}$ and it became a controversial issue of the highest degree, a celeber quaestio, as Salgado de Somoza called it in Labyrinthus Creditorum. $^{73}$ With the creation of the modern codes in the Igth century, application of the rule as a general principle of law was definitively abandoned. None of the Codes in Europe contains such a rule. ${ }^{74}$ As a principle of private international law, the Roman Law rule has been sustained much longer.

In the international field, during the last century, the doctrine in Europe was strongly influenced by Savigny is who proposed to everywhere recognize the effects of bankruptcy declared by the court of the debtor's domicile. In Italy, the strongest support of this theory of "universality" of bankruptcy ${ }^{76}$ came from the jurists Carle and Fiore, who advocated in $1872^{77}$ and $1873^{78}$ a sole bankruptcy declaration at the commercial domicile of the debtor with extraterritorial effect in every country. They made, however, an exception: if a debtor has distinct and separate establishments, the courts of the location of each establishment should have jurisdiction for a separate bankruptcy declaration. Carle, referring to Straccha, ${ }^{79}$ argued that two establishments, located in one country or in different countries, might appear so separate to the respective creditors that these creditors might have con-

70. Cf. Straccha, De mercatura (1558) Tract. de decoctoribus, ult. p. 21 ; J. Voet, Comaientarius ad Pandectas (I704) L. XIV, tit. 4 , No. 7.

7T. Cf. 2 Salgado de Somoza, Labyrintius creditorum (i653) c. i2, n. 73.

72. Cf. 2 Mantica, De tacitis et ambiguis conventionibus (I63I) De coniractibus, tit. 23, ex. n. 32 ; RoDEnbURGH, Tract. DE JURE CONJUGUM. DE JURE QUOD ORITUR E STATUTORUM DIVERSITATE (165I) tit. 2, c. 5, ex. n. 16, reprinted in 2 BOULLENOIS, TRAITÉ DES STATUTS (I766) in fine, p. 49.

73. SALGado, op. cit. supra note $7 \mathrm{I}$, at n. 68 .

74. Cf., however, Old Commercial Code of Japan, $\$$ ro45 (2), in force until rg22: "If a bankrupt has carried on two or more businesses with separate capitals, the creditors of each individual business are satisfied in preference out of the assets of the business in question." 3 De Becker, Commentary on the Commercial Code of Japan (1913) 272.

75. 8 Savigny, System des heutigen Römischen Rechts (I849) § 374; Savigny, Private International Law (Guthrie trans. I888) $26 \mathrm{I}$. Cf. J. Voet, op. cit. supra note 70, L. XX, tit. 4, No. I2; I PUFENDORF, OBs. JUR. UNIV. (I744) obs. 217; DABELOW, LEHRE VOM CONCURSE (I80I) 746.

76. In Italy, this doctrine had already been sustained by ANSALdus, DE commerCio ET Mercatura (1689) Disc. II, n. 25; 3 De Luca, Disc. 10, No. 5, De credito (1755) tit. 10, n. 32.

77. CARLE, LA DOTTRINA GIURIDICA DEL FALLIMENTO NEL DIRITTO INTERNAZTONALE PRIVATO (I872) No. 22 ; CARLE, LA FaILlite DANS le DRoIT INTERNATIONAL PRIVE (Dubois trans. I875).

78. Fiore, Del fallimento secondo il diritto privato internazionale (i873) 20; Fiore, I Diritto Internazionale Privato (4th ed. ig02) No. 4 I8.

79. Straccha, loc. cit. supra note 70 : "ex bono et aequo et optima ratione inductum est, ut creditores separatim in negotiationibus quarum causa crediderunt, vocentur." 
sidered only the capital attributed to each of the establishments. In such a case, the assets and the creditors of each establishment should be dealt with separately. ${ }^{80}$ In 1880 , the matter of bankruptcy was discussed at the Juridical Congress in Turin. With Carle acting as reporter, the principle of "universality" of bankruptcy was accepted as a basis for international treaties, but no exception or special provision was made for cases of "separate establishments". ${ }^{81}$ Nor was an exception made in the model treaty drafted at The Hague in 1925 by the 5th Conference of Private International Law, ${ }^{82}$ or in any European treaty on bankruptcy. ${ }^{83}$ Neither in Italy ${ }^{84}$ nor elsewhere in Europe ${ }^{85}$ has the theory requiring separation of creditors, in the case of debtors with separate establishments in different countries, had any followers among leading modern authors. Any separation would be incompatible with the basic principle that "the whole property of the debtor is a common pledge for all his creditors." 86

In South America, on the contrary, the doctrine of Carle and Fiore concerning "separate establishments" had considerable influence. In Brazil, a decree of 1878 relating to the execution of foreign judgments ${ }^{87}$ provided: if a debtor domiciled abroad has two distinct and separate establishments, one abroad and one in Brazil, and is declared bankrupt abroad, local creditors, $i$. e., those to be paid in Brazil, can require the bankruptcy of the establishment in Brazil and will be paid

80. CARLE, loc. cit. supra note 77. Criticized by Dubois in the translation (n. 49). Followed by voN BAR, Private InTernational LAW (Gillespie trans. I892) 1023.

8I. ATTI DEL SECONDO CONGRESSO gIURIDICO ITALIANo INTERNAZIONALE (Turin I88r ) Disc. p. I8; CluNET, I880, 625; voN BAR, stipra note 80, at I054.

82. ACTES DE LA 5e Conférence de dROIT international PRIVÉ de La Haye (1925) 352; CLUNET, I926, 822.

83. References in Nadelmann, supra note I9, at Sor. Cf. Swiss Fed. Trib., Feb. I7, 1928, ClunET, 1928, 802 (applying the Franco-Swiss Treaty of I869). But see: same Trib., April 30, 19I4, A. S. 40, III, I23 (in a non-treaty case).

84. I Bonezli, Del fallimento (2d ed. 1923) No. 75, 3 id. No. $780 ; 3$ Diena, TratTato DI DIRITro INTERNAZIONALE (I905) 5I4; Gemma, Il fallimento nei rapporti internazionali (I897) No. I4, in Encrclopedia Giuridica; 2 Ramella, Tratrato del FALIIMIENTO (2d ed. I9I5) No. $74 \mathrm{I}$.

85. See 7 Travers, Droit Commercial International, pt. I (I935) Nos. II,378 to $I I, 399$.

For France, 8 Lyon-Caen \& Renault, Traité de droit commerctal (5th ed. with Amiaud I936) No. I303; 3 Percerou, Des faillites ET BanQueroutes (2d ed. with Deserteaux I938) No. I735; Cass. civ., March II, I9I3, D. I9I4.I.185 with note by Pick, Ciunet, I913, gro.

For Scotch law, see Royal Bank of Scotland v. Scott, Smith and Co. (Stein's case) (I8I3) I7 FAC. CoLI. 72, I Rose (App.) 462 (partnership carrying on trade in Edinburgh and in London).

For English law, cf. In re P. Macfaden \& Co. [I908] I K. B. 675 (bankruptcy in England and in India of a firm operating under different methods in England and India; agreement between the trustees of the two bankruptcies for pooling all the assets and distributing them ratably among all creditors sanctioned by court). See Dicex, Conflict of Laws (5th ed. I932, by A. B. Keith) 787 ; Cheshire, Private INTERNATIONAL LAW (2d ed. 1938) 474 .

86. Code NAPOLÉoN, $\$ \S 2092,2093$.

87. Decree No. 6982 of July $27,1878, \S$ I9. 
prior to the creditors of the other establishment. This rule is still in force in Brazil. ${ }^{88}$

In the same year, the Lima Congress of Jurists prepared a draft which, following Fiore, ${ }^{89}$ provided for a sole bankruptcy declaration, with effect everywhere, by the court of the commercial domicile of the debtor, admitting, however, multiple bankruptcies in the case of a debtor with "two or more separate and distinct commercial enterprises in different countries." 90 At the International South-American Congress of Montevideo, 1888-89, Fiore's suggestions, supported by the reporter Gonzalo Ramirez of Uruguay, ${ }^{91}$ were accepted as a basis for the bankruptcy provisions in the Treaty of International Commercial Law. This Treaty, ${ }^{92}$ ratified by Argentine, Bolivia, Paraguay, Peru and Uruguay, provides for a single bankruptcy declaration by the court of the commercial domicile of the debtor with extraterritorial effect everywhere, even if the debtor "trades occasionally in another country, or maintains there agencies or branches operated for account and under the responsibility of the main house." ${ }^{83}$ But the possibility of multiple bankruptcies is admitted in the case of a debtor with two or more "independent commercial houses" in different countries. ${ }^{94}$ No provision in the Treaty of 1889 states that the creditors of each independent house must be paid out of "their" house prior to other creditors. If there are multiple bankruptcies, the priority of local creditors follows from the domestic laws of these countries relating to multiple bankruptcies.

The Montevideo Treaties have been revised by the Second Congress for Private International Law of Montevideo I939-1940.95 Upon the proposal of the delegate from Uruguay, a provision has been added in the new Treaty of International Commercial Law stating that, even in the case of a single bankruptcy declaration, local claims, i. e., those to be paid in one country, have priority upon the assets located in that country. ${ }^{96}$ A similar provision has been incorporated in that part of

88. Bankruptcy Law No. 5746 of $1929, \S \mathrm{I} 6 \mathrm{I}$ (trans. in Nadelmann, loc. cit. supra note I9, n. I12); C. C. P., \$ 788 .

89. See report of Arenas, Actas y Tratados celbrrados por el Congreso Internacional SUd-AMERicano de MoNTEvideo (ed. IgII) 76.

90. Id. at 54. The same principle was applied in a Treaty of 1824 between Prussia and Saxon Weimar.

9I. See report of Gonzalo Ramfrez, id. at 676-696.

92. Id. at 842; Clunet, I897, 900; Report of THe INTERnational AMerican Congress $(1890) 876$.

93. Art. 35 of the Treaty of International Commercial Law, loc. cit. supra note 92.

94. Art. 36,39 (2) of the Treaty.

95. Segundo Congreso Sudamericano de Derecho Internacional Privado de MonTEVIDEO I939-1940 (Buenos Aires 1940).

96. Art. $48(2)$ of the Treaty of International Commercial Law, loc. cit. supra note 95, at 255. See Videla Aranguren, Las quiebras en el Congreso de Montevideo 1939/1940 (1942) 5 (2d ser.) Revista ARGentina DE DeRECho INTERNACIONAL 363 et seq. 
the new Treaty of International Procedural Law ${ }^{97}$ which deals with the insolvency of non-merchant debtors. ${ }^{98}$ These modifications were strongly opposed by the delegates from Argentine as being incompatible with the treaty-system and contrary to the purpose of such a treaty. ${ }^{90}$ The delegate from Uruguay supported the new provisions contending they only purport "to give preference to creditors who have their claim located in one state and have taken into account, when contracting, the property existing in that state", and that they are in accord with the spirit in which Gonzalo Ramirez drafted the Treaty of $1889 .{ }^{100}$ Whether or not they are in accord with Gonzalo Ramirez, ${ }^{101}$ it is evident that they result in a complete negation of Fiore's theory which furnished the basis for the Treaty.

The new Treaties, signed by Argentine, Bolivia, Brazil, Colombia, Paraguay, Peru and Uruguay, have not yet been ratified. The latest developments show a strengthening of the tendency in South America to protect local interests. ${ }^{102}$ The contents of the Treaties are of interest for the Treaty-partners only, but a policy of increasing local protectionism is of concern for all countries already confronted with the priority rule applied against creditors from abroad by Argentine, Paraguay, Peru and Uruguay, in the case of multiple bankruptcies.

The Bustamante Code, adopted at Havana in 1928 by the Sixth Conference of American States, ${ }^{103}$ contains conflict of laws rules relating to bankruptcy. The Code distinguishes between the case of a debtor with "one domicile" and a debtor with several separate establishments in different countries. If the debtor has only "one domicile",

97. Art. 20 of the Treaty of International Procedural Law, supra note 95, at I42.

98. See Videla Aranguren, El concurso civil de acreedores en el Congreso de Montevideo r939/1940 (194I) 4 (2d ser.) REVISTA ARGENTINA DE DERECHO INTERNACIONAL 342.

99. Prof. Gonzáles Gowland of Buenos Aires before the Commission of Commercial Law, March 15, 1940. Cf. Videla Aranguren and Thamis, note (a) sub Nadelmann, El reconocimiento de los arreglos americanos en el exterior (1943) $29 \mathrm{RE}-$ VISTA JURfDICA ARGENTINA LA LEY, n. 167.

Ioo. Prof. Vargas Guillemette of Montevideo before the Commission of Commercial Law, March I5, I940.

iol. C $f$. Gonzalo Ramírez, El derecho procesal internactonal en el CongReso JURídico DE MONTEVIDeO (I892); Carlos Alberto Alcorta, El Profesor Meili y el regimen de la quiebra en el Congreso Sud-Americano de Montevideo de 1889 (1924) I4 JURISPRUDENCIA ARGENTINA, Sec. doct. 66.

102. In Brazil, a draft of a new Bankruptcy Law by Trajano de Miranda Valverde, published in DIÁRIo OfICIAL, January 26, I940, grants priority to "local" creditors not only in the case of "distinct and separate establishments", as does the law No. 5746 now in force (supra note 88), but whenever a bankrupt debtor with domicile in Brazil and abroad has "establishments, branches, or agencies" in Brazil (art. 173 of the draft). This is "to better protect the national interest". MINISTERIo DA JUSTICA E NEGOCTOS INTERIORES, ANTE-PROJETO DE LEI DE FALENCIAS (1940) 73 .

$C f$. the reservations to the same effect made by Brazil when signing the Montevideo Treaty of 1940 on International Commercial Law, supra note 95 , at 258 .

I03. THe INTternational Conferences of AMERICAN STATES, I889-1928 (I93I)

$367 ; 4$ Hudson, International Legislation (I93I) 2340; 86 League of Nations, TREATY SERTES (I929) 362. 
there may be only one bankruptcy proceeding for all his assets and all his debts in the contracting states. ${ }^{104}$ But if a debtor has "divers economically entirely separate commercial establishments" in more than one state, there may be as many bankruptcies as establishments. ${ }^{105}$ The Code was drafted in a spirit different from that of the Montevideo Treaty of $1889 .{ }^{108}$ Bustamante, justifying the provisions admitting multiple bankruptcies in the case of "separate establishments", states this provision becomes applicable only if the separate establishment constitutes a distinct personality from the legal viewpoint. ${ }^{107}$ According to Bustamante, the rule follows a line normally applied also in the internal law. ${ }^{108}$ If the text must be interpreted in this sense, the provision might have been omitted as superfluous. Evidently, in case of lack of identity of debtors, multiple bankruptcies are necessary. The problem whether or not an establishment has a separate juridic personality is not a bankruptcy question. Conflict of laws rules applicable to this problem are contained in other parts of the Code. ${ }^{109}$

To date, I 5 Latin-American States have ratified the Bustamante Code. ${ }^{110}$ The United States postponed adherence to the convention. ${ }^{111}$ Peru, a partner of the Montevideo Treaty of 1889 , is a signatory of the Bustamante Code. With the priority clause in its bankruptcy statute, it thus deals in three different ways with the priority problem, dependent upon whether the Montevideo Treaty, the Bustamante Code, or domestic law is applicable. Adherence to the Code does not seem to exclude application by Peru in a Peruvian bankruptcy of

I04. Bustamante Code, §414.

I05. Bustamante Cone, § 415 .

I06. "Since then the idea that bankruptcy of a debtor must be unique and universal, has become a deep rooted proposition. International commerce every day becomes a more decisive factor in juridical life and requires that debtors and creditors do not encounter, the first for his credit, and the second for his rights, obstacles and perils in the national laws and at the frontiers. The creditor is creditor relative to all the assets of his debtor, and he has less confidence, and, by this, is less disposed to give credit, if in the case of possible economic difficulties his guaranties will diminish. Capital emigrates like persons and needs, as the individual, what may be called equality of economic rights. The facilities and advantages for the debtor who needs financial help from somebody, are in direct relation to the dangers which the law permits the creditor to incur on the day of recovery. The law exists for the well-being of the people, and instead of being egoistic, they should, and they can be, cosmopolite and human." BusTAMANTE Y SiRven, LA CoMisión DE JuRISCONSUltos de RIO DE JANEIRo Y EL DERECHo INTERNACIONAL (I927) No. I87 (author's trans.).

I07. 3 Bustamante y Sirven, Derecho Internactonal Privado (2d ed. 1934) No. 1887 ; Bustamante y Sirven, Manual de Derecho Internacional Privado (I939) No. 263 .

No. 1888 .

io8. 3 Bustamante y Sirven, Derecho Internactonal Privado (2d ed. I934)

iog. Bustamante Code, $\$ \S 32,252$.

I IO. Bolivia, Brazil, Chile, Costa Rica, Cuba, Dominican Republic, Ecuador, El Salvador, Guatemala, Haiti, Honduras, Nicaragua, Panama, Peru, Venezuela.

III. The InTERnational Conferences of AMERICan States, I889-I928 (I93I)

371; Lorenzen, The Pan-American Code of Private International Law (1930) 4 Tulane L. Rev. 499, 520. 
its own local priority rule against debts contracted abroad ${ }^{112}$ even with respect to Code-partners who do not have such a rule. Maintenance of such an inequality between Code-partners, in the opinion of the writer, is a weakness of the Code. ${ }^{113}$

\section{Discussion}

Any country which adheres to, and applies, the principle of strict equality between domestic and foreign creditors must be concerned with foreign legislation which does not provide for the same equality. Creditors placed at a disadvantage abroad can expect, and in fact they do expect from their respective governments, appropriate measures to terminate any situation of inferiority in the protection of their rights. ${ }^{114}$

Provisions in some bankruptcy statutes which give priority to local creditors in the case of multiple bankruptcies, or in other cases, evoke criticism in countries which do not have such a rule. Creditors from these countries risk the loss of their rights abroad by the operation of the priority system, although at home full equality is guaranteed to creditors from abroad. One cannot wonder that these creditors express their dissatisfaction.

One of the arguments advanced in support of the rule giving local creditors priority in the case of multiple bankruptcies is that such a rule is necessary to protect domestic creditors against similar hostile foreign legislation. Most countries have no priority rule. Existence or non-existence of a priority rule in a specific country is easy to ascertain. If retaliation were the sole argument to support the rule, logic would require that application of the priority rule be restricted to such cases of multiple bankruptcies where, in fact, the law governing the foreign bankruptcy contains the priority rule. ${ }^{115}$

The other argument supporting the rule is that the text must be interpreted as being limited to the case of debtors with separate establishments in different countries, and that in such a case it is just and

II2. See note 46 supra.

I13. Article I of the Bustamante Code provides:

"(I) Foreigners belonging to any of the contracting States enjoy, in the territory of the others, the same civil rights as are granted to nationals.

"(2) Each contracting State may, for reasons of public order, refuse or subordinate to special conditions, the exercise of certain civil rights by the nationals of the remaining States, and any of the latter States may in such cases refuse or subordinate to special conditions the same exercise to the nationals of the former."

This guaranty of equal civil rights does not seem to exclude application of priority rules not based on "nationality." Cf. note io supra.

II4. As to the question of diplomatic protection, see Borchard, The Diplomatic Protection of Citizens Abroad (I9I5) 104.

II5. Cf. the reciprocity clause in the law of some countries, note 8 supra. RrvaROLA, op. cit. supra note 57 , No. I409, n. I, advocates, as a measure of self-defence, admission of foreign creditors generally only if the foreign assets were put at the disposal of the Argentine bankruptcy judge. No such self-defence is justified, or necessary, if abroad all creditors are admitted on equal terms. 
equitable to separate the creditors of each establishment. If the rule be limited to the case of "separate establishments", the rule still would not be acceptable to the countries not having the rule. Unequal treatment of creditors of the same debtor, even if he runs more than one business, is incompatible with basic principles of Anglo-Saxon as well as Civil law.

An academic discussion of the merits of the "separate establishments" doctrine can hardly be expected to furnish new views on the subject. The arguments for and against the proposition are known; they have been expounded many times. The striking fact in the evolution of the problem since Ulpian's time is the abandonment of the rule requiring separation of creditors of "separate establishments" as a principle of general law and its survival, in some countries, only as a conflict of laws rule. The main doctrinal question now is: Why can the rule, improper as a general proposition, be equitable as a conflict of laws rule? If $\mathrm{D}$ has two "separate establishments", why should $\mathrm{C}$, a creditor in contact with one, have priority rights upon this establishment if the other is located abroad, but not if both are located in the same country? In other words, why should an establishment which in contemplation of law is not a separate entity, be treated as such in the case where the owner has another establishment abroad which also is not legally a separate entity?

In the absence of a corporation law admitting the creation of entities with separate legal personality, a general rule like that in the Digest may have been useful, if not necessary. Today such a principle must conflict with the rules which domestic corporation law furnishes relating to the existence and creation of separate legal entities.118 These rules may prescribe the formation of separate corporations where necessary in special fields to insure protection of the general public. ${ }^{11 \tau}$

The fact that the "separate establishment" concept is not used as a principle of general law renders its application difficult even between

Cf. Decree of July 27, 1934, of Belgian Congo: "Art. 128. In the case of bankruptcy declared in the Congo and abroad, the trustee named in the Congo is alone competent for pursuing in the Congo the bankruptcy operations. Art. 129. Upon the production of the judgment of installation the trustee of the bankruptcy declared abroad is to be admitted to the bankruptcy in the Congo in the name of the creditors who have proved their claims abroad. Art. 130. In the case of the two preceding articles the assets liquidated in the Congo will be distributed without any distinction based on nationality among all creditors, provided that the trustee named abroad admits in the bankruptcy which he administers the creditors established in the Congo."

II6. For the Latin-American conceptions as to juristic persons, see ROMERO DEL Prado, La personas JURf́dicas EN EL DERECho INTERNACIONAL PRIVAdO (1926) I63; Schuster, The Judicial Status of Non-Registered Foreign Corporations in Mexico (1933) 7 Tulane L. Rev. 34I ; Voelkel, $A$ Comparative Study of the Law of LatinAmerica Governing Foreign Business Corporations (1939) I4 TUlane I. REv. 42.

II7. See note 34 supra. Cf. the Banking Law of Chile ( $\$$ I3) and of Peru ( $\$ 33$ ), granting priority on local assets to creditors domiciled in the country. 
partners to a treaty working with this fiction. This results from the recent debates at Montevideo where attempts to define "separate establishments" were made, but finally abandoned.118 If applied unilaterally against creditors from a country not bound by treaty, ${ }^{119}$ any system must create resentment which makes equal admission of such creditors dependent upon the flexible "separate establishment" concept ${ }^{120}$ administered and interpreted by courts foreign to the creditors.

From a practical viewpoint, it can be said that cases of "separate establishments" to which the rule might apply are diminishing. There is a general trend to form separate corporations, each with its own legal personality, in cases where "separate establishments" are owned by the same person, or group of persons, especially if they are to be operated in different countries. One may ask, therefore, whether the remaining cases of "separate establishments" justify continuance of a conflict of laws rule recognizing a legal entity fiction which contradicts the general law.

An interesting variation of a local priority rule is the provision mentioned in this paper ${ }^{121}$ which admits debts contracted abroad on an equality basis only to the extent the money was, in fact, invested in the domestic business of the debtor. As to any kind of rule which differentiates between "foreign" and "domestic" debts for their ranking in bankruptcy distributions, the question to be asked is whether there are creditors who knowingly would accept a limitation of their rights on assets in the country where the rights "accrued or arose", especially if the debtor is domiciled elsewhere. This can hardly be expected. The creditors would risk seeing the main assets located somewhere else when the debtor becomes insolvent. Nor can creditors be expected to accept a rule which makes the protection of their rights dependent upon the question whether or not the debtor has invested the money in his home state. Therefore, creditors aware of the existence of a provision of this kind will be reluctant to extend credit' under such circumstances.

II8. See report Sapena Pastor, supra note 95, at 239.

I19. See page 6r5 supra. Cf. App. Paris, May II, I927, Cluner, 1928, 654 (case of Banque Française pour le Brésil declared bankrupt in France and in Brazil).

I20. At Montevideo, the branches of the National City Bank of New York in Montevideo, Buenos Aires, Lima, Santiago, were cited as an example for "separate establishments" by Bustamante y RIVERA (Peru). Proceedings of Commission of Comprercial LAw, March 15, I940. Contra: Bustansante y Sirven, Manual de Derecho Intzrnactonal. Privado (I939) No. 263. Cf. The New York Life Insurance Company case, Progress of Continental Law in the rgth Century (I9I8) 5I2, 5I4. (It was held in Argentine, on appeal, that the branch offices of the Company in Montevideo and Buenos Aires were simply agencies and not independent commercial houses: Argentine Sup. Ct., Oct. 27, 1903, Farlos 98, 169.)

12I. Bankruptcy Law of Pera, $\$ 26(3)$, page 609 supra. $C f$. the provision in the New York Civil Practice Act applicable to foreign corporations in receivership, note 25 supra. 
There is an old doctrine which asserts that in any case "local creditors must have priority on local assets." Does such a doctrine still deserve any discussion? It results in what may be called the opposite of an invitation to persons from abroad to give credit to the country. No country now can afford to act that way, nor can it be assumed that any country wants to do so. However, the doctrine still finds supporters. If applied by a country with less capital of its own citizens abroad than foreign capital inside the country, a local priority rule is advantageous to the creditors of the country. It is wrong to underestimate the force of such practical considerations. They are sometimes very frankly expressed, and the local priority rule is declared the system best fitted to the economic situation of the country. This may be an "utilitarian, not to say egoistic" viewpoint..122 If blame must be accorded, one wonders whether it is deserved more by the "egoist" than by the party tolerating the disadvantageous situation. The answer depends upon the possibility of finding means to change the situation.

What means are available to a country desirous of protecting its own citizens against prejudice resulting from the application elsewhere of a priority rule favoring domestic creditors? Most of the countries have a statutory provision or a decisional rule that a creditor who has received a dividend in a foreign court will get his share in the domestic bankruptcy distribution only after the other creditors have been paid a dividend equal to that received by the creditor abroad. ${ }^{123}$ This so-

122. Cf. ORIONe, loc. cit. supra note 68.

123. U. S. A. Bankruptcy Act, $\$ 65$ (d) : "Whenever a person shall have been adjudged a bankrupt by a court without the United States and also by a court of bankruptcy, creditors residing within the United States shall first be paid a dividend equal to that received in the court without the United States by other creditors before creditors who have received a dividend in such court shall be paid any amounts." This protection should be given, it seems, not only to "creditors residing within the United States", but to all creditors except those having received a dividend abroad.

Carpenter v. Ludlum, 69 F. (2d) 19I, 92 A. L. R. 590 (1934), certiorari denied, 292 U. S. 655 (1934) (applied against creditor paid in Tennessee under priority rule, note 22 supra).

The principle was extended to cases where a creditor had obtained a lien by legal proceedings upon the bankrupt's property in a foreign country. In re Pacat Finance Corp., 295 Fed. 394, 40I, 4II (D. C. N. Y. 1923) ; In re Pollmann, I56 Fed. 221 (D. C. N. Y. 1907).

England. Selkrig v. Davies, 2 Dow. 230, 249 (1814); Ex parte Wilson, L. R. 7 Ch. App. 490 (1872); Banco de Portugal v. Waddell, 5 App. Cas. 161, 175 (1880). Cf. the Indian case, Yokohoma Specie Bank, Ltd. v. Curlender \& Co., (I926) 96 I. C. 459. Scotland. Stewart v. Auld (I85I) I3 D. I337; cf. Clydesdale Bank v. Anderson (1890) 27 Sc. L. R. 493 .

France. App. Paris, July 22, I929, Clunet, I929, 1095.

Switzerland. Fed. Trib., May I9, 1904, A. S. 30.I.442.

Courts in GERMany and Austria held in the opposite sense, leaving the creditor as not being accountable for what he had received abroad: $R$. G., March 28, I903, E. 54, 193; ObH. G., Oct. I4, 1930, Jur. W., 1931, 2199.

In the NETHERLANDS, $\$ 203$ of the Bankruptcy Law provides that creditors must turn over to the trustee in bankruptcy what they have received abroad.

The same was prescribed by a former Scottish bankruptcy statute, 54 GEo. III, c. $137, \S 5$ I; $c f .2$ Bell's Commentaries on the Law of Scotland (7th ed. 1870) 573. 
called "hotch-pot" rule is designed to restore the equality among creditors. The measure is not always effective, however, inasmuch as a creditor may already have received abroad more than would have been his share on an equality basis in a general distribution. In such a case no means exist to restore, by set-off, the equality among creditors. ${ }^{124}$

The classic remedy for a situation where citizens are deemed unequally treated abroad is retaliation. Statutes in some countries provide for a system of automatic retortion in admitting foreign creditors in bankruptcy proceedings upon the condition that full reciprocity is guaranteed. ${ }^{25}$ Other statutes reserve to the government the right to subject claims of foreign creditors to retaliatory measures. ${ }^{128}$ These measures may take the form of reciprocation, $i$. e., application of the foreign rule under like conditions; $e . g$., in the case of multiple bankruptcies. They may go further by generally depriving creditors of a specific country of the right to equally participate in bankruptcy distributions. ${ }^{127}$ Sometimes, courts themselves retort even in the absence of a statutory provision to that effect. ${ }^{128}$ In at least one country, France, the absence of a statutory reciprocity clause is deliberate and is the expression of the belief in the persuasive power of a good example. ${ }^{12 \theta}$

Retaliation does not give creditors of a specific debtor the share due to them upon the basis of full equality. It does submit creditors of another country to a corresponding disadvantage and, thus, tests the wisdom of applying the local priority rule. The efficacy of such a measure depends upon many circumstances. If retaliation is exercised against a country with more capital of its own citizens abroad than foreign capital within its borders, the measure may prove highly effective. In the opposite case this might be improbable.

However, the economic aspect of the situation must also be considered. A country with more foreign capital within its borders than

124. For a discussion of the question whether, and when, a domestic creditor who has obtained payment abroad, but does not seek to participate in the domestic bankruptcy, can be made to disgorge what he has recovered abroad, see CHESHIRE, PrIvate INTERNational Law (2d ed. 1938) 483; Dicey, Conflict of Laws (5th ed. by A. B. Keith, 1932) 372; NIBOYET, SIREY, I938.2.I93, note sub App. Colmar, Nov. 22, I934, Clunet, I935, 912.

125. See note 8 supra.

126. See note 9 supra.

127. Cf. Reprisal Decree of Louis XVI, 8 Denisart, Collection de DEcisions (I789) 4I7, note 6 supra.

128. App. Paris, May II, 1927, Cluner, r928, 654 (involving the priority rule applied in Brazil).

Cf. Hilton v. Guyot, I59 U. S. I13 (I895), where conclusive effect of a foreign judgment was denied by the U. S. Supreme Court on the ground of lack of reciprocity. 129. The French Supreme Court, in 1885, favored adoption of an amendment to the French Code providing that in bankruptcy proceedings foreign creditors shall be admitted on a reciprocity basis. The amendment did not pass. See CluNEr, 1886, 50r. "The liberal and broad principle of the French law is of a nature to provoke reflections among legislators of foreign states, and, perhaps, to induce those who stepped aside or would step aside, to follow the same way." Thaller, op. cit. supra note 65 , at 37 I (author's trans.). 
capital of its own citizens abroad may be the more vulnerable economically. The possibility of maintaining a local priority rule against the wishes of foreign creditors is then a question of economic power. If the result of a dispute concerning the fairness of the controversial rule is to be unwillingness abroad to continue creditor relations, the repercussions may well be a price higher than can be afforded for maintaining the rule.

Under contemporary conditions where isolation from the rest of the world is impossible for any country, a rule to the disadvantage of foreign creditors can hardly be upheld against the wishes of such creditors if effectively expressed. Legal retaliation nowadays is dispensable, not so much for idealistic reasons, but because there are more efficient means of securing satisfactory solutions. One method lies in focusing the attention of all interested parties on the problem.

\section{CoNCLUSION}

Equal admission of creditors in bankruptcy distributions, irrespective of nationality or place of residence, has proved the only workable system in a world which, for its very existence, depends upon undisturbed international commerce. A grant of priority rights to local creditors, whatever form it may assume, contradicts the principle of equality. It is legal isolationism, as incompatible with international commerce as economic or political isolationism. All countries are interested in the maintenance of equality among all creditors as a condition for international commercial relations. ${ }^{130}$ Protection of equality, therefore, is service to a common cause.

Right or wrong, the belief exists that equality for creditors from abroad is not granted everywhere, in law as well as in fact. The special situations here discussed are only some of many, though probably the most important, in relation to which doubts have been expressed as to the existence of equality for all creditors. They need a clarification which is difficult to obtain without the cooperative effort of all concerned.

For clarification, and for the suppression of discrimination where it may exist, both in legislation and in legal practices, international organizations can aid considerably. This has successfully been done by the International Chamber of Commerce acting as a clearing-house among its members. ${ }^{131}$ As all countries are not represented in the in fine.

130. Cf. 6 Carlos Calvo, Droit International (5th French ed. 1896) No. I68

I3I. See Resolution of the Ioth Congress of the International Chamber of Commerce, Copenhagen, I939, ANNALES DE Droit CoMmercial, 1939, SUPPlEMENT docuMENTAIRE SUR LE DROIT COMPARE DES FAILLITES, No. 3,3 . 
Chamber, its work suffered from geographic limitations. It is a fact that in this Hemisphere the treatment in bankruptcy proceedings of creditors from abroad is not the same everywhere. Rules exist in some countries of the South which differ from that of the North and of the European countries.

The Eighth International Conference of American States has created in 1938 a new Permanent Committee of Jurists, with its seat in Lima, to study and prepare unification of the Civil and Commercial Laws of America. ${ }^{132}$ If there is one subject which, in the interest of international commerce, requires uniformity, it is the legal position of foreign and non-resident creditors. It is, therefore, surprising that the Permanent Committee for the Unification of the Civil and Commercial Laws did not, in its first report, ${ }^{133}$ include this subject among those mentioned for consideration. It was said on another occasion that "it will be eminently wise to limit an effort to harmonize laws affecting a number of states to what is feasible as respects both subject matter and sphere of application." 184 To achieve complete uniformity of the bankruptcy laws, for example, is "a utopian dream". ${ }^{185}$ However, uniformity relating to a specific question as vital as that of the rights of creditors from abroad in bankruptcy proceedings, is a goal which not only can, but must, be achieved. Strong elements in the commercial as well as the purely legal sphere will support any move towards uniformity.

The Inter-American Bar Association has, since its creation, paid special attention to the protection of foreign investors. ${ }^{136}$ In the resolution for sufficient protection of foreign investments, the First Conference has urged the members of the Association to exert influence in their respective countries for legislative uniformity in this matter. It seems that the resolution should be amplified by a statement of policy regarding the desired uniformity. In the opinion of the writer, no other policy can be envisaged than that of equal protection for domestic creditors and creditors from abroad without any exception.

132. International Conferences of American States, First Supplement 1933-1940 (1940) 236; (1940) 34 AM. J. INT. L. SUPP. I91.

I33. See Oleachea, La unificación del derecho privado en América (I941) I REvista Peruana De Derecho Internactonal 89, 5 Revista de Derecho y Ciencias PoLf́tICAS 422.

134. Yntema, Comparative Research and Unification of Law (address) (1942) $4 \mathrm{I}$ Mich. L. Rev. 26I, 266; 29 Revista JuRfdica ARgentina LA LEY, March 4, 1943.

135. Percerou and Nadelmann, Changes in Bankruptcy Legislation Caused by the Economic Crisis (General Report to the second international Congress of Comparative Laz, The Hague), ANNALES DE Drort ComanerCIal, 1937, 181, 196; (1938) i2 J. N. A. REF. BANKR. 68, 87 (translation).

i36. Cf. note 2 supra. The recently created Committee on Comparison of Civil and Commercial Laws has chosen as one of the subjects for its investigations the position in bankruptcy proceedings of creditors from abroad. See Dolz, La reunion del Consejo de la Federación Interamericana de Abogados in Washington (1942) $5 \mathrm{RE}-$ vISTA DEL Colegio DE ABOGados de IA Habana 457; Vallance, Post-War Plans of the Inter-American Bar Association (I943) 37 AM. J. InT. L. I06, II3. 